\title{
Odontocete Stranding Patterns in the Main Hawaiian Islands (1937-2002): How Do They Compare with Live Animal Surveys? ${ }^{1}$
}

\author{
Daniela Maldini, ${ }^{2,3,4}$ Lori Mazzuca, ${ }^{5}$ and Shannon Atkinson ${ }^{4,6}$
}

\begin{abstract}
In this study we (1) synthesized $65 \mathrm{yr}$ of odontocete stranding data around the main Hawaiian Islands (1937-2002); (2) analyzed stranding patterns and trends over time; and (3) compared occurrence patterns based on sightings of live animals with stranding data and evaluated the compatibility of these data sets. From 1937 to 2002, 202 odontocete strandings were recorded by the National Marine Fisheries Service, Pacific Islands Regional Office. Strandings increased through time due to increased reporting effort and occurred throughout the year. The four most common of 16 species reported were Kogia spp. (18\%), spinner dolphins (Stenella longirostris) (15\%), striped dolphins (Stenella coeruleoalba) (11\%), and sperm whales (Physeter macrocephalus) (10\%). The highest proportion of strandings was recorded on $\mathrm{O}^{\prime} \mathrm{ahu}(48 \%)$, followed by Maui/ Lāna'i (24\%), Kaua'i (12\%), Hawai'i (11\%), and Moloka'i (5\%). Comparison with four previously published live animal survey studies suggests that stranding records are a good indicator of species composition and yield reasonable data on the frequency of occurrence of species in the region they cover.
\end{abstract}

Systematic studies of odontocetes around the main Hawaiian Islands are limited to a few species such as spinner dolphins, Stenella longirostris (Norris et al. 1994,

\footnotetext{
${ }^{1}$ Funding for this study was provided by the Pacific Marine Life Foundation. The opinions expressed in this paper are solely those of the authors and do not reflect the opinions of the National Marine Fisheries Service, Pacific Islands Regional Office. Manuscript accepted 30 March 2004.

${ }^{2}$ Corresponding author.

${ }^{3}$ University of Hawai'i at Mānoa, Hawai'i Institute of Marine Biology, P.O. Box 1346, Kāne'ohe, Hawai'i 96744.

${ }^{4}$ Current address: Alaska SeaLife Center, 301 Railway Avenue, P.O. Box 1329, Seward, Alaska 99664 (phone: 907-224-6375; fax: 907-224-5014; e-mail: daniela_maldini@alaskasealife.org).

${ }^{5}$ National Oceanic and Atmospheric Administration/ National Marine Fisheries Service/Alaska Fisheries Science Center/National Marine Mammal Laboratory, Kodiak Laboratory, 301 Research Court, Kodiak, Alaska 99615.

${ }^{6}$ University of Alaska Fairbanks, School of Fisheries and Ocean Sciences and Alaska SeaLife Center, 301 Railway Avenue, P.O. Box 1329, Seward, Alaska 99664.
}

Pacific Science (2005), vol. 59, no. 1:55-67

(C) 2005 by University of Hawai'i Press

All rights reserved
Benoit-Bird 2003, Lammers 2003), and bottlenose dolphins, Tursiops truncatus (Baird et al. 2001, 2002). Strandings (Shallenberger 1981, Nitta 1991, Mazzuca et al. 1998, 1999), historical records (Shallenberger 1981, Tomich 1986), opportunistic sightings (Shallenberger 1981), and dedicated surveys (Mobley et al. 2000, 2001, Baird et al. 2003, Barlow 2003, Maldini 2003) have helped to identify 19 species of odontocetes known to occur in that area. Abundance and distribution patterns were documented by Mobley et al. (2000, 2001) for the winter and spring of 1993-1998 and 2000 and, more recently, by Baird et al. (2003) and Barlow (2003). Only one study has documented year-round patterns (Maldini 2003), but it was limited in geographical scope. Until routine scientific monitoring of abundance and distribution patterns of odontocetes is undertaken, strandings documented in the Hawaiian Islands are useful to fill knowledge gaps.

Nitta (1991) reported all cetacean stranding data in Hawaiian waters between 1937 and 1987 but provided no analysis of trends and occurrence patterns; Mazzuca et al. (1998) analyzed strandings of humpback whales (Megaptera novaeangliae) between 1972 and 1996, and Mazzuca et al. (1999) analyzed 


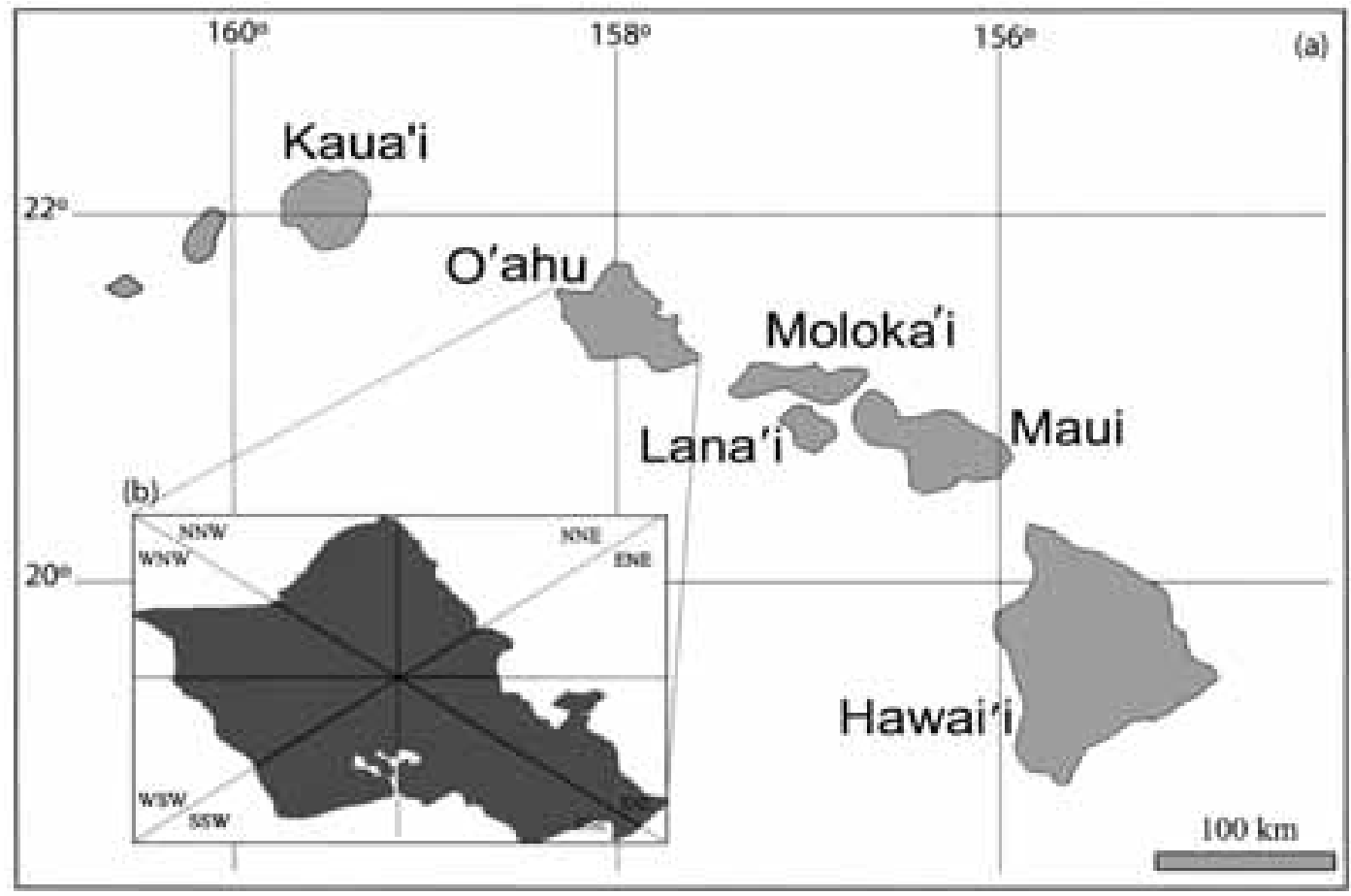

FIgure 1. (a) Map of the main Hawaiian Islands; (b) diagram of the method used to subdivide each of the main Hawaiian Islands into sectors, according to compass direction, using the island of $\mathrm{O}^{\prime}$ ahu as an example.

cetacean mass strandings between 1957 and 1998. In this study we: (1) synthesized $65 \mathrm{yr}$ of odontocete stranding data around the main Hawaiian Islands (1937-2002); (2) analyzed stranding patterns and trends over time; and (3) compared occurrence patterns based on sightings of live animals with stranding data and evaluated the compatibility of those data sets.

\section{MATERIALS AND METHODS}

\section{Study Area}

The Hawaiian Island Archipelago consists of a group of volcanic islands, including eight major islands and 124 islets, that stretch in a $1,500-\mathrm{km}$ crescent from Kure Island in the northwest to the island of Hawai' $i$ in the southeast. The archipelago encompasses an area of $16,729 \mathrm{~km}^{2}$ and is isolated from any other landmass by ca. 4,600 km of deep oceanic water. The five largest islands, from south to north, are Hawai'i, Maui, Lāna'i, Moloka'i, O'ahu, and Kaua'i, which are known as the main Hawaiian Islands and are the focal region of this study (Figure 1).

\section{Compilation of Stranding Data}

Stranding data from 1937 to 2002 on the main Hawaiian Islands were obtained from the National Marine Fisheries Service, Pacific Islands Regional Office (NMFS/PIR) and previously published work (Shallenberger 1981, Nitta 1991, Mazzuca et al. 1999). The date, species (when identifiable), location of stranding, and number of animals present were obtained from the stranding records included in the NMFS/PIR database (summarized in Appendix 1). Exact latitude and longitude coordinates were not available in the NMFS/PIR database; therefore, the closest town to the stranding site was used to indicate location (Appendix 1). 


\section{Stranding Patterns}

Differences in stranding frequency by species, island, sector (each representing a different compass direction [see definition following]), and season were investigated for all the main Hawaiian Islands. The database did not contain any strandings for the islands of $\mathrm{Ni}^{\text {'i }}$ ihau and Kaho'olawe (the federal stranding network is inactive on those islands because beach access on $\mathrm{Ni}^{\text {i }}$ ihau is limited to native Hawaiians, and Kaho'olawe is uninhabited), and strandings for Maui and Lāna'i were combined because only three strandings were reported on Lāna'i.

To determine if the distribution of strandings was skewed toward a particular compass direction, each island was divided into eight wedge-shaped sectors (Figure 1). The length of the coastline delimited by each sector was calculated (in kilometers) using a measuring tool included in the ArcView (1997) software package. Number of strandings per kilometer of coastline was calculated for each compass direction and for each island. Although accounting for population size on each island was considered, the time frame of the database was too wide and population size on some Hawaiian Islands has varied considerably within the period of time in question, making potential search effort too complex to take into account with this method. Comparisons among islands and sectors were accomplished using a two-way analysis of variance (ANOVA). A Tukey's multiple comparison was used to explain significant differences between islands or sectors. A Kruskal-Wallis test was used to detect significant differences in number of strandings per month.

\section{Comparison with Live Animal Surveys}

The species composition in the stranding record for all main Hawaiian Islands was compared with four recent studies employing either boat or aerial surveys to determine abundance and distribution patterns of cetaceans in the same region: (1) Mobley et al. (2000), (2) Baird et al. (2003), (3) Barlow (2003), and (4) Maldini (2003). These studies covered overlapping areas of the main Hawaiian Islands but generally differed by the extent of coverage.

Mobley et al. (2000) conducted aerial surveys within ca. $42 \mathrm{~km}$ of the main Hawaiian Islands covering an area of $71,954 \mathrm{~km}^{2}$ between February and April 1993, 1995, and 1998. Baird et al. (2003) conducted boatbased surveys covering $8,461 \mathrm{~km}$ of trackline around the main Hawaiian Islands in May and June 2003. Although they used different survey platforms, Mobley's and Baird's studies covered both inshore and offshore areas at a similar range of depths. Barlow (2003) conducted systematic ship-based surveys of $20,000 \mathrm{~km}$ of transect lines around the entire U.S. Economic Exclusion Zone (EEZ) surrounding Hawai' $i$ in summer/fall 2002. That study surveyed the deepest waters but lacked coverage close to shore. Maldini (2003) conducted year-round aerial surveys of waters 0 to $500 \mathrm{~m}$ deep around the island of O'ahu between 1998 and 2000.

Frequency of occurrence of each odontocete species in the stranding data was compared with its occurrence in each of the four live animal studies using $z$-statistics. These studies are referred to as Baird, Barlow, Mobley, and Maldini, respectively, in the Results.

\section{RESULTS}

\section{Total Strandings and Trends over Time}

Between 1937 and 2002, 202 odontocete strandings were recorded in the main Hawaiian Islands by the NMFS/PIR. Although records in the NMFS/PIR database dated back to 1937 , the first odontocete stranding was documented in 1950. One hundred and eighty-two strandings were identifiable to species, seven to genus (six Kogia spp. and one Stenella spp.), two were doubtful identifications (one short-finned pilot whale, Globicephala macrorbynchus, and one Kogia spp.) because of the state of decomposition of the carcass, and 11 were unidentified (Appendix 1). The temporal trend in the data showed an increase in the number of strandings with time (Figure 2). 


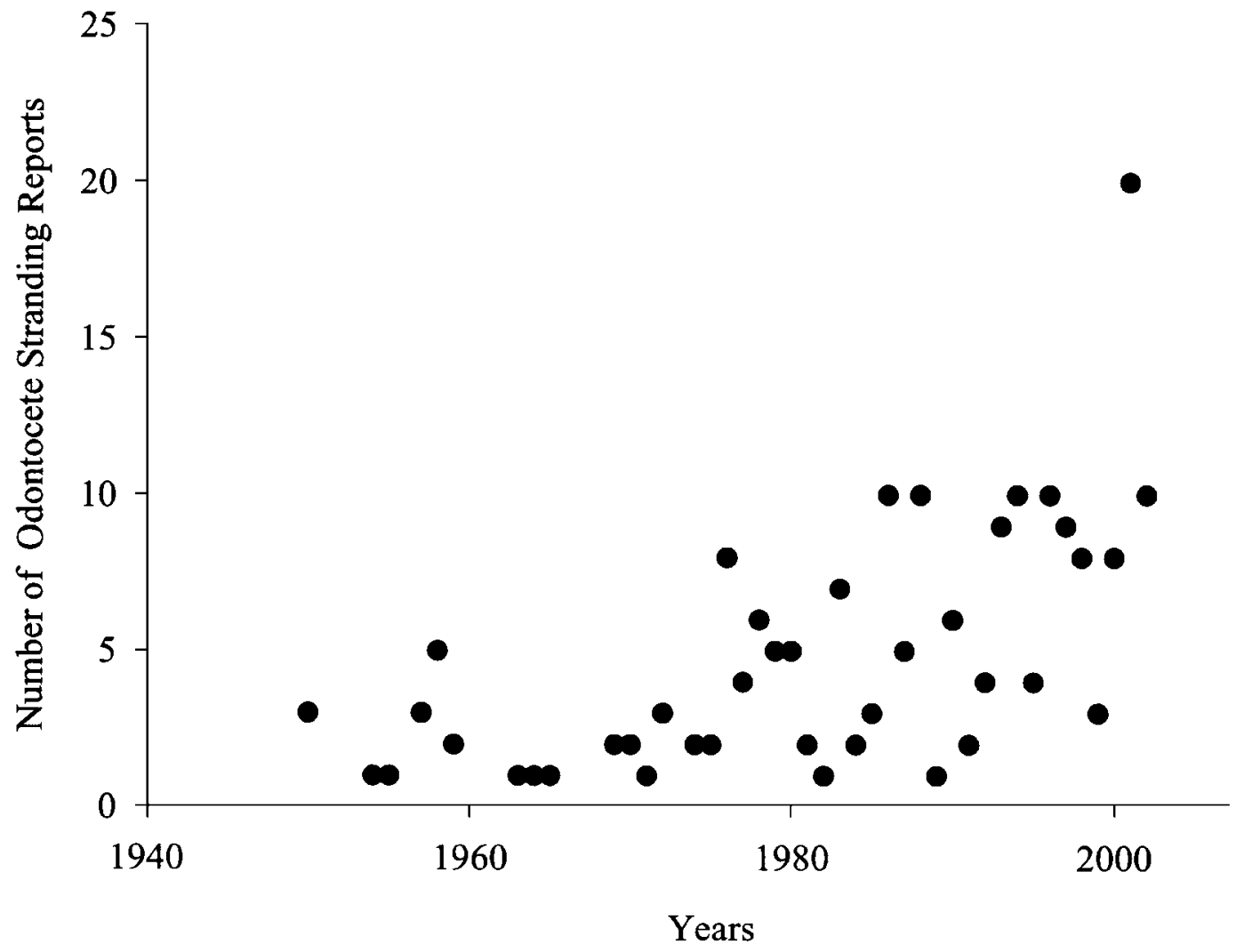

FIGURE 2. Number of odontocete strandings recorded on the main Hawaiian Islands by the National Marine Fisheries Service, Pacific Islands Regional Office between 1937 and 2002. The number of strandings increased substantially throughout the years.

\section{Stranding Patterns}

The highest proportion of strandings was recorded on O'ahu (48\%), followed by Maui/ Lāna'i (24\%), Kaua'i (12\%), Hawai'i (11\%), and Moloka'i (5\%). Average number of strandings per $100 \mathrm{~km}$ of coastline was significantly different between islands (ANOVA: $F=0.226, \mathrm{df}=4, P=0.008$; Figure 3) but not between sectors throughout the Islands (ANOVA: $\quad F=1.299, \quad \mathrm{df}=7, \quad P=0.287$; Figure 4). A Tukey's multiple comparison supported the conclusion that differences between islands were explained by the differences between $\mathrm{O}^{\prime}$ ahu and Hawai'i. Strandings occurred throughout the year and the difference in number of strandings per month was not significant (Kruskal-Wallis: $H=17.873$, $P=0.085)$.
Species Composition and Comparison with Live Animal Surveys

Sixteen species were included in the stranding record, although pygmy sperm whales (Kogia breviceps) and dwarf sperm whales (Kogia sima) were pooled as Kogia spp. for analysis. All 16 species were observed by Barlow, 12 by Mobley, 14 by Baird, and Maldini recorded only 7 (Table 1). In addition, Barlow found two species that were not reported in strandings: Fraser dolphins (Lagenodelphis hosei) and Longman's beaked whales (Indopacetus pacificus).

The four most common species throughout the main Hawaiian Islands, as percentage of total strandings, were Kogia spp. (primarily pygmy sperm whales; $18 \%$ ), spinner dolphins $(15 \%)$, striped dolphins (Stenella coeruleoalba; 


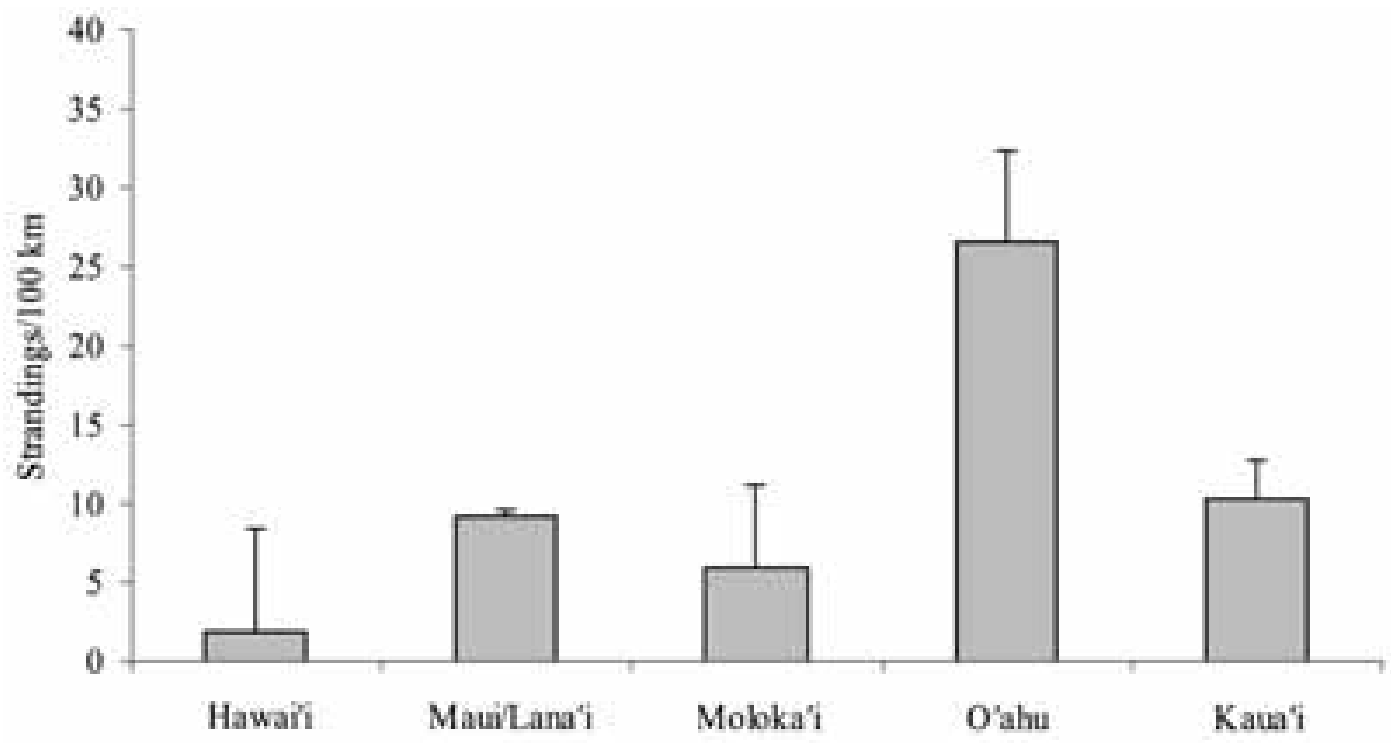

Figure 3. Number of strandings on the main Hawaiian Islands by island between 1937 and 2002. Bars show standard error.

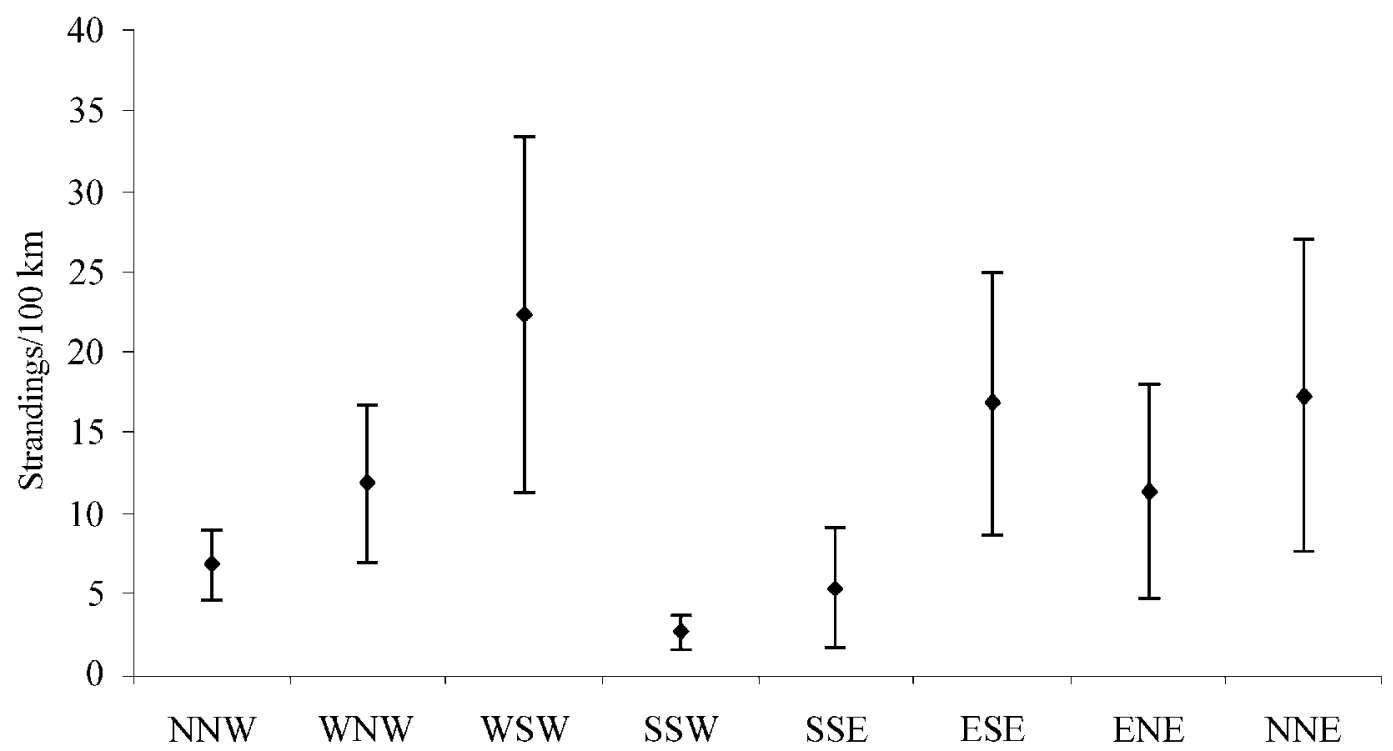

FIgURE 4. Number of strandings on the main Hawaiian Islands by sector between 1937 and 2002. Bars show standard error.

$11 \%$ ), and sperm whales (Physeter macrocephalus; $10 \%)$. Spinner dolphins were among the four most common species in three out of four live animal survey studies.
Following are some of the more notable results for the comparisons between the occurrence of each species in the stranding database and its occurrence in each of the 
TABLE 1

Comparative Summary of Species Occurring around the Main Hawaiian Islands as Proportion of Total Occurrences Based on Stranding Reports (1937-2002) and Systematic Surveys of Live Animals Using Aerial (Mobley et al. 2000, Maldini 2003) and Boat-Based Platforms (Baird et al. 2003, Barlow 2003) (Results of $z$-Statistic Comparing Strandings with Each of the Live Studies are reported Only When Significant)

\begin{tabular}{|c|c|c|c|c|c|}
\hline Species & $\begin{array}{c}\text { Strandings } \\
(1937-2002)\end{array}$ & $\begin{array}{l}\text { Mobley } \\
\text { et al. }(2000)\end{array}$ & $\begin{array}{l}\text { Maldini } \\
(2003)\end{array}$ & $\begin{array}{l}\text { Barlow } \\
(2003)\end{array}$ & $\begin{array}{l}\text { Baird } \\
\text { et al. (2003) }\end{array}$ \\
\hline Kogia spp. & 0.18 & - & - & $\begin{array}{l}0.05 \\
z=2.869 \\
P=0.004\end{array}$ & $\begin{array}{l}0.07 \\
z=2.715 \\
P=0.007\end{array}$ \\
\hline $\begin{array}{l}\text { Spinner dolphin } \\
\text { (Stenella longirostis) }\end{array}$ & 0.15 & 0.19 & 0.18 & $\begin{array}{l}0.04 \\
z=2.600 \\
P=0.009\end{array}$ & 0.14 \\
\hline $\begin{array}{l}\text { Striped dolphin } \\
\text { (Stenella coeruleoalba) }\end{array}$ & 0.11 & $\begin{array}{l}0.01 \\
z=4.539 \\
P<0.001\end{array}$ & - & 0.11 & $\begin{array}{l}0.01 \\
z=3.318 \\
P<0.001\end{array}$ \\
\hline $\begin{array}{l}\text { Sperm whale } \\
\text { (Physeter macrocephalus) }\end{array}$ & 0.10 & 0.08 & - & 0.18 & $\begin{array}{l}0.01 \\
z=3.089 \\
P=0.002\end{array}$ \\
\hline $\begin{array}{l}\text { Melon-headed whale } \\
\text { (Peponcephala electra) }\end{array}$ & 0.08 & $\begin{array}{l}0.01 \\
z=3.552 \\
P<0.001\end{array}$ & - & $\begin{array}{l}0.01 \\
z=2.173 \\
P=0.030\end{array}$ & $\begin{array}{l}0.02 \\
z=2.103 \\
P=0.035\end{array}$ \\
\hline $\begin{array}{l}\text { Short-finned pilot whale } \\
\text { (Globicephala macrorbynchus) }\end{array}$ & 0.07 & $\begin{array}{l}0.27 \\
z=5.271 \\
P<0.001\end{array}$ & $\begin{array}{l}0.41 \\
z=6.366 \\
P<0.001\end{array}$ & 0.14 & 0.12 \\
\hline $\begin{array}{l}\text { Bottlenose dolphin } \\
\text { (Tursiops truncatus) }\end{array}$ & 0.06 & $\begin{array}{l}0.18 \\
z=3.607 \\
P<0.001\end{array}$ & $\begin{array}{l}0.18 \\
z=2.695 \\
P=0.007\end{array}$ & 0.09 & $\begin{array}{l}0.30 \\
z=5.669 \\
P<0.001\end{array}$ \\
\hline $\begin{array}{l}\text { Spotted dolphin } \\
\text { (Stenella attenuata) }\end{array}$ & 0.05 & 0.09 & 0.07 & 0.08 & $\begin{array}{l}0.18 \\
z=3.602 \\
P<0.001\end{array}$ \\
\hline $\begin{array}{l}\text { Rough-toothed dolphin } \\
\text { (Steno bredanensis) }\end{array}$ & 0.04 & 0.03 & 0.01 & $\begin{array}{l}0.14 \\
z=2.829 \\
P=0.005\end{array}$ & 0.09 \\
\hline $\begin{array}{l}\text { Pygmy killer whale } \\
\text { (Feresa attenuata) }\end{array}$ & 0.03 & - & - & 0.01 & 0.01 \\
\hline $\begin{array}{l}\text { False killer whale } \\
\text { (Pseudorca crassidens) }\end{array}$ & 0.03 & $\begin{array}{l}0.08 \\
z=2.025 \\
P=0.043\end{array}$ & $\begin{array}{l}0.10 \\
z=1.975 \\
P=0.048\end{array}$ & 0.01 & 0.01 \\
\hline $\begin{array}{l}\text { Cuvier's beaked whale } \\
\text { (Ziphius cavirostris) }\end{array}$ & 0.03 & 0.03 & - & 0.02 & - \\
\hline $\begin{array}{l}\text { Risso's dolphin } \\
\text { (Grampus griseus) }\end{array}$ & 0.03 & 0.01 & - & 0.05 & - \\
\hline $\begin{array}{l}\text { Blainville's beaked whale } \\
\text { (Mesoplodon densirostris) }\end{array}$ & 0.01 & 0.03 & 0.04 & 0.01 & 0.04 \\
\hline $\begin{array}{l}\text { Killer whale } \\
\text { (Orcinus orca) }\end{array}$ & 0.01 & - & - & 0.02 & 0.01 \\
\hline $\begin{array}{l}\text { Fraser dolphin } \\
\text { (Lagenodelphis hosei) }\end{array}$ & 0.01 & - & - & 0.01 & - \\
\hline $\begin{array}{l}\text { Longman's beaked whale } \\
\text { (Indopacetus pacificus) }\end{array}$ & 0.01 & - & - & 0.01 & - \\
\hline
\end{tabular}

four live animal studies. The arrows in parentheses indicate whether frequency of occurrence was higher $(\uparrow)$ or lower $(\downarrow)$ in the stranding database than in the live animal study being compared. Details of these statistical differences are summarized in Table 1.

Differences between the stranding data and Barlow were significant for four species: 
Kogia spp., ( $\uparrow)$; spinner dolphins, $(\uparrow)$; melonheaded whales (Peponcephala electra), $(\uparrow)$; and rough-toothed dolphins (Steno bredanensis), $(\downarrow)$. Differences between the stranding data and Mobley were significant for five species: striped dolphins, $(\uparrow)$; melon-headed whales, $(\uparrow)$; short-finned pilot whales, $(\downarrow)$; bottlenose dolphins, $(\downarrow)$; and false killer whales (Pseudorca crassidens), $(\downarrow)$. Differences between the stranding data and Maldini were significant for three species: short-finned pilot whales, $(\downarrow)$; bottlenose dolphins, $(\downarrow)$; and false killer whales, $(\downarrow)$. Differences between the stranding data and Baird were significant for six species: Kogia spp., ( () ; striped dolphins, $(\uparrow)$; sperm whales, $(\uparrow)$; melon-headed whales, $(\uparrow)$; bottlenose dolphins, $(\downarrow)$; and spotted dolphins, ( $\downarrow$ ). Fraser dolphins and Longman's beaked whales were not compared because they were not present in the stranding database.

\section{DISCUSSION}

Despite increased effort and a more organized stranding network, the overall number of strandings recorded for a 65 -yr period in the main Hawaiian Islands is low when compared with other geographic areas. These low odontocete densities are supported by recent wide-area line transect surveys (Barlow 2003). As a comparison, a $200-\mathrm{km}$ stretch of coast between the Loire and Girond estuaries on the central French Atlantic coast yielded 259 odontocete strandings between 1972 and 1986 (Duguy and Wisdorff 1988). On O'ahu, which has a similar length of coastline (ca. $225 \mathrm{~km}$ ), only 30 strandings were reported during the same period.

The location of stranding events may be substantially affected by bottom topography, tides, currents, and weather patterns such as the northeast trade winds, which prevail most of the year (Klinowska 1985, MignucciGiannoni et al. 1999). Furthermore, sharks, which are abundant in Hawaiian waters, are known to scavenge on marine mammal carcasses and may consume many of them before they reach land (Long and Jones 1996, Heithaus 2001).

It is not surprising that almost half (48\%) of the total number of stranding reports were on the island of $\mathrm{O}^{6} \mathrm{ahu}$, which has the largest human population and the most crowded beaches. This indicates that a considerable proportion of strandings may be either missed or not reported on other main Hawaiian Islands, where large portions of the coastline are remote. The frequency of stranding reports, standardized by the length of the coastline for each island, suggests that considerable effort is needed to expand the stranding network on the island of Hawai' $i$, where number of strandings per kilometer of coastline was lowest. In fact, Hawai' $i$ has long stretches of coastline that are not easily accessible and it also has a low population density relative to the other islands.

The number of strandings per kilometer, for each compass direction, was not significantly different for all islands combined (Figure 3). However, there was a low number of strandings reported on some islands; therefore, interisland differences in stranding patterns by compass direction could not be further explored.

Inspection of results by sector for all islands indicates that strandings are generally less common in south-facing sectors, which are less exposed to onshore wind conditions than other sectors (Figure 4). Strandings occurred in all months with no significant trend. In contrast, results of year-round aerial surveys conducted around O'ahu (Maldini 2003) indicated an increased frequency of odontocete sightings in the winter.

The species composition in the stranding database reflects the composition of species found in live animal surveys and advocates for the usefulness of stranding data as a source of information when other data are not available. Only the wide-area surveys conducted by Barlow (2003), which included the deepest waters within the U.S. EEZ surrounding the Hawaiian Islands, resulted in a number of species comparable with, and actually larger than, that in the stranding database.

The frequency of occurrence of some species that are not easily detected in systematic surveys due to factors such as size, surfacing behavior, or pelagic life history may be better represented by stranding data. This may be 
the case for Kogia spp., which had the highest frequency of stranding but were either not detected or detected with low frequency during surveys, and for melon-headed whales, which are not cryptic but could be misidentified in the field. Balcomb (1987) described melon-headed whales as preferring the open ocean and as not being particularly abundant in Hawaiian waters although present year-round.

Some differences in frequency of occurrence of different species between strandings and live animal surveys can be explained by the types of habitat surveyed in each of the four studies. For example, the frequency of occurrence of spinner dolphins in Barlow (2003) was lower than in all other studies, but that of rough-toothed dolphins was higher. Spinner dolphins are generally found in shallow waters close to shore, an area that Barlow (2003) did not survey. Conversely, Barlow's surveys covered waters to the north of the main Hawaiian Islands, where most roughtoothed dolphin sightings occurred. In addition, Barlow's surveys confirmed that striped dolphins are among the most abundant species in pelagic waters around the main Hawaiian Islands and recorded a frequency of occurrence of sightings similar to that predicted by strandings. All other live animal surveys occurred closer to shore and were not as extensive so that the occurrence of striped and rough-toothed dolphins was misrepresented.

Short-finned pilot whales and bottlenose dolphins appear to be more common than predicted by strandings. This discrepancy is difficult to interpret. Short-finned pilot whales were particularly abundant around O'ahu (Maldini 2003).

There appear to be two ecotypes of bottlenose dolphins (inshore and offshore) in Hawai'i (Baird et al. 2003). Inshore bottlenose dolphins appear to prefer areas close to the shelf break and are generally localized (Baird et al. 2002). Little is known about the offshore ecotype. Stranding patterns for these two ecotypes may differ, but available stranding data did not distinguish between the two.

In conclusion, stranding patterns around the main Hawaiian Islands suggest overall low odontocete densities, which are supported by Barlow (2003). Stranding patterns do not suggest seasonality; an increase in strandings over time is likely due to an increase in reporting effort over time. Comparison with live animal survey data suggests that stranding records are a good indicator of species composition and yield reasonable data on the frequency of occurrence of species in the region they cover. However, comparisons with live animal surveys are indispensable to identify and interpret anomalous stranding patterns.

ACKNOWLEDGMENTS

We acknowledge the NMFS/PIR for collecting and organizing the Hawaiian stranding database and David Nichols of PIR for providing access to that database. We also acknowledge the Pacific Islands Fishery Science Center, the U.S. Fish and Wildlife Service, the Hawai'i State Department of Land and Natural Resources-Hawaiian Islands Stranding Response Group, the U.S. Coast Guard, and the Maui Police Department for sending personnel on site to collect stranding data. We also thank the following individuals: Marlee Breese, Lou Consiglieri, Paul Forestell, David Haas, Chris Haley, Don Heacock, John Henderson, Naomi McIntosh, John Naughton, Gene Nitta, Ken Norris, Edward Shallenberger, and many anonymous contributors. Thanks also go to Whitlow Au, Lisa Ballance, Joseph Mobley, Sue Moore, Marcia Muto, Paul Nachtigall, and other anonymous reviewers who provided invaluable input to the manuscript.

\section{Literature Cited}

ArcView. 1997. Version 3.2 (http://www.esri. $\mathrm{com} /$ software/arcview/).

Baird, R. W., A. M. Gorgone, A. D. Ligon, and S. K. Hooker. 2001. Mark-recapture estimate of bottlenose dolphins (Tursiops tuncatus) around Maui and Lana'i, Hawai' $\mathrm{i}$ during the winter of 2000/2001. NMFS/ SWFSC Tech. Rep. 40JGNF0-00262.

Baird, R. W., A. M. Gorgone, and D. L. Webster. 2002. An examination of movements of bottlenose dolphins between islands in the Hawaiian Island chain. 
NMFS/SWFSC Tech. Rep. 40JGNF110270.

Baird, R. W., D. J. McSweeney, D. L. Webster, A. M. Gorgone, and A. D. Ligon. 2003. Studies of odontocete population structure in Hawaiian waters: Results of a survey through the main Hawaiian Islands in May and June 2003. NOAA Tech. Rep. AB133F-02-CN-0106.

Balcomb, K. C., III. 1987. The whales of Hawaii, including all species of marine mammals in Hawaiian and adjacent waters. Marine Mammal Fund, San Francisco, California.

Barlow, J. 2003. Cetacean abundance in Hawaiian waters during summer/fall of 2002 . SWFSC Admin. Rep. LJ-03-13.

Benoit-Bird, K. J. 2003. Dynamics of the Hawaiian mesopelagic boundary community and their effects on predator foraging. Ph.D. diss., University of Hawai'i at Mānoa, Honolulu, Hawaíi.

Duguy, R., and D. Wisdorff. 1988. Cetacean stranding and metereological factors on the central French Atlantic coast. Oceanol. Acta 11 (3): 227-233.

Heithaus, M. R. 2001. Predator-prey and competitive interactions between sharks (order Selachii) and dolphins (suborder Odontoceti): A review. J. Zool. (Lond.) 253 (1): 53-68.

Klinowska, M. 1985. Interpretation of the UK cetacean stranding records. Rep. Int. Whaling Comm. 35:459-467.

Lammers, M. O. 2003. The behavior and broadband acoustic signaling of Hawaiian spinner dolphins (Stenella longirostris). Ph.D. diss., University of Hawai'i at Mānoa, Honolulu, Hawai'i.

Long, D. J., and R. E. Jones. 1996. White shark predation and scavenging on cetaceans in the eastern North Pacific Ocean. Pages 293-307 in A. P. Klimley and D. G. Ainley, eds. Great white sharks: The biology of Carcharodon carcharias. Academic Press, San Diego.

Maldini, D. 2003. Abundance and distribution patterns of odontocetes around $\mathrm{O}^{\prime} \mathrm{ahu}$ and Penguin Banks, Hawai'i. Ph.D. diss., University of Hawai'i at Mānoa, Honolulu, Hawaici.
Mazzuca, L., S. Atkinson, and E. Nitta. 1998. Deaths and entanglements of humpback whales, Megaptera novaeangliae, in the main Hawaiian Islands, 1972-1996. Pac. Sci. 52:1-13.

Mazzuca, L., S. Atkinson, B. Keating, and E. Nitta. 1999. Cetacean mass strandings in the Hawaiian Archipelago, 1957-1998. Aquat. Mamm. 25 (2): 105-114.

Mignucci-Giannoni, A. A., B. PintoRodriguez, M. Velasco-Escardero, R. A. Montoya-Ospina, N. M. JimenezMarrero, M. A. Rodriguez-Lopez, E. H. Williams Jr., and D. Odell. 1999. Cetacean strandings in Puerto Rico and the Virgin Islands. J. Cet. Res. Manage. 12:191-198.

Mobley Jr., J. R., S. S. Spitz, K. A. Forney, R. Grotefendt, and P. H. Forestell. 2000. Distribution and abundance of odontocete species in Hawaiian waters: Preliminary results of 1993-98 aerial surveys. SWFSC Admin. Rep. LJ-00-14C.

Mobley, J., S. Spitz, and R. Grotefendt. 2001. Abundance of humpback whales in Hawaiian waters: Results of 1993-2000 aerial surveys. Admin. Rep. Hawaiian Islands Humpback Whale National Marine Sanctuary, Office of National Marine Sanctuaries/National Oceanic and Atmospheric Administration, U.S. Department of Commerce/Department of Land and Natural Resources, State of Hawai'i, Honolulu, Hawai'i.

Nitta, E. T. 1991. The marine mammal stranding network for Hawai'i, an overview. Pages 55-62 in John E. Reynolds III and Daniel K. Odell, eds. Marine mammal strandings in the United States: Proceedings of the 2nd Marine Mammal Stranding Workshop, 3-5 December 1987, Miami, Florida. NOAA Tech. Rep. NMFS 98.

Norris, K., B. Wursig, R. S. Wells, and M. Wursig. 1994. The Hawaiian spinner dolphin. University of California Press, Los Angeles.

Shallenberger, E. W. 1981. The status of Hawaiian cetaceans. Tech. Rep. Mar. Mamm. Comm. PB82109398.

Tomich, P. Q. 1986. Mammals in Hawai'i: A synopsis and notational bibliography. 2nd ed. Bishop Mus. Spec. Publ. 76. 
Appendix 1

List of Odontocete Strandings Recorded between 1937 and 2002 in the Main Hawaiian Islands (Although Strandings Have Been Reported since 1937, No Odontocetes Were Found until 1950)

\begin{tabular}{|c|c|c|c|c|}
\hline Year & Species & $\begin{array}{l}\text { No. of } \\
\text { Individuals }\end{array}$ & Location & Island \\
\hline 1950 & Cuvier's beaked whale & 1 & - & O'ahu \\
\hline 1950 & Killer whale & 1 & South Point & Hawai'i \\
\hline 1950 & Cuvier's beaked whale & 1 & South Point & Hawai'i \\
\hline 1954 & Sperm whale & 1 & Kahuku & O’ahu \\
\hline 1955 & Melon-headed whale & 1 & Wailupe Circle & O'ahu \\
\hline 1957 & Short-finned pilot whale & 1 & Punalu'u & O'ahu \\
\hline 1957 & Short-finned pilot whale & 2 & Waikīkī & O'ahu \\
\hline 1957 & Kogia spp. & 1 & Wailupe Circle & O'ahu \\
\hline 1958 & Short-finned pilot whale & 1 & Kalihi Beach & Kaua'i \\
\hline 1958 & Short-finned pilot whale & 24 & Keōmuku Beach & Lāna'i \\
\hline 1958 & Short-finned pilot whale & 1 & Waikīkī & O'ahu \\
\hline 1958 & Short-finned pilot whale & 12 & Kalihi Beach & Kaua'i \\
\hline 1958 & Striped dolphin & 1 & Ala Wai & O'ahu \\
\hline 1959 & Short-finned pilot whale & 28 & 'Anini Beach & Kaua'i \\
\hline 1959 & Short-finned pilot whale & 1 & Waimānalo & O'ahu \\
\hline 1963 & Pygmy sperm whale & 1 & Bellows Beach & O'ahu \\
\hline 1964 & Melon-headed whale & 1 & Kahuku & O‘ahu \\
\hline 1965 & Melon-headed whale & 1 & Lahaina & Maui \\
\hline 1969 & Rough-toothed dolphin & 1 & Wai'anae & O'ahu \\
\hline 1969 & Spinner dolphin & 1 & Sandy Beach & O'ahu \\
\hline 1970 & Cuvier's beaked whale & 1 & Mākaha & O'ahu \\
\hline 1970 & Spinner dolphin & 1 & Kahului Harbor & Maui \\
\hline 1971 & Melon-headed whale & 1 & Ke'ehi Lagoon & O'ahu \\
\hline 1972 & Spinner dolphin & 1 & Makapu'u & O’ahu \\
\hline 1972 & Melon-headed whale & 1 & Kahuku & O'ahu \\
\hline 1972 & Pygmy sperm whale & 1 & Lā'ie & O'ahu \\
\hline 1974 & Pygmy sperm whale & 1 & Kalaupapa & Moloka'i \\
\hline 1974 & False killer whale & 1 & Kailua Beach & O'ahu \\
\hline 1975 & Spotted dolphin & 1 & Hale‘iwa & O'ahu \\
\hline 1975 & Pygmy killer whale & 1 & Hāwī & Hawai'i \\
\hline 1976 & Spinner dolphin & 1 & Sea Life Park & O’ahu \\
\hline 1976 & Pygmy sperm whale & 2 & Kīhei & Maui \\
\hline 1976 & Melon-headed whale & 1 & Punalu'u & $\mathrm{O}^{\prime} \mathrm{ahu}$ \\
\hline 1976 & Sperm whale & 1 & Kahuku & O'ahu \\
\hline 1976 & Rough-toothed dolphin & 18 & Kīhei & Maui \\
\hline 1976 & Rough-toothed dolphin & 1 & Kā'anapali & Maui \\
\hline 1976 & Rough-toothed dolphin & 4 & Kỉhei & Maui \\
\hline 1976 & Unidentified odontocete & 1 & Kā'anapali & Maui \\
\hline 1977 & Spinner dolphin & 1 & Mokulē'ia & O'ahu \\
\hline 1977 & Striped dolphin & 1 & Punalu'u & O'ahu \\
\hline 1977 & Kogia spp. & 1 & Waimea & Kaua'i \\
\hline 1977 & Risso's dolphin & 1 & Wailuku & Maui \\
\hline 1978 & Spinner dolphin & 1 & Kailua & O'ahu \\
\hline 1978 & Spinner dolphin & 1 & Port Allen & Kaua'i \\
\hline 1978 & Risso's dolphin & 1 & Kāhala & O'ahu \\
\hline 1978 & Striped dolphin & 1 & Hale'iwa & O'ahu \\
\hline 1978 & Risso's dolphin & 1 & Pāpōhaku & Moloka'i \\
\hline 1978 & Striped dolphin & 1 & Reef Runway & O’ahu \\
\hline 1979 & Pygmy sperm whale & 1 & Kīhei & Maui \\
\hline 1979 & False killer whale & 1 & Mōkapu & O'ahu \\
\hline 1979 & Short-finned pilot whale & 1 & Hanauma Bay & O'ahu \\
\hline 1979 & Striped dolphin & 1 & Kahuku & O'ahu \\
\hline 1979 & Sperm whale & 1 & Barbers Point & O'ahu \\
\hline 1980 & False killer whale & 1 & Mōkapu & O'ahu \\
\hline
\end{tabular}


Appendix 1 (continued)

\begin{tabular}{|c|c|c|c|c|}
\hline Year & Species & $\begin{array}{l}\text { No. of } \\
\text { Individuals }\end{array}$ & Location & Island \\
\hline 1980 & Spinner dolphin & 1 & Ka'a'awa & O'ahu \\
\hline 1980 & Pygmy sperm whale & 1 & Kīhei & Maui \\
\hline 1980 & Striped dolphin & 1 & Kinhei & Maui \\
\hline 1980 & Striped dolphin & 1 & Kailua Beach & O'ahu \\
\hline 1981 & Pygmy killer whale & 4 & Mā‘alaea & Maui \\
\hline 1981 & Cuvier's beaked whale & 1 & Hilo & Hawai'i \\
\hline 1982 & Unidentified odontocete & 1 & Kīhei & Maui \\
\hline 1983 & Pygmy killer whale & 1 & South Point & Hawai'i \\
\hline 1983 & Bottlenose dolphin & 1 & Kepuhi Beach & Moloka' ${ }^{6}$ \\
\hline 1983 & Unidentified odontocete & 1 & Waiakalua-Pīla'a & Kaua'i \\
\hline 1983 & Melon-headed whale & 1 & Mākaha & O'ahu \\
\hline 1983 & Striped dolphin & 1 & Punalu'u & O'ahu \\
\hline 1983 & Sperm whale & 1 & Hā'ena & Kaua'i \\
\hline 1983 & Risso’s dolphin & 1 & Kīhei & Maui \\
\hline 1984 & Short-finned pilot whale & 1 & Kahana Bay & O’ahu \\
\hline 1984 & Striped dolphin & 1 & Pauwalu Harbor & Moloka ${ }^{6}$ \\
\hline 1985 & Bottlenose dolphin & 1 & Mokulēia & O’ahu \\
\hline 1985 & Melon-headed whale & 1 & Mokule'ia & $\mathrm{O}^{\prime} \mathrm{ahu}$ \\
\hline 1985 & Sperm whale & 1 & Kāne'ohe & O'ahu \\
\hline 1986 & Spinner dolphin & 1 & Kāne'ohe & O'ahu \\
\hline 1986 & Striped dolphin & 1 & Lanikai & O'ahu \\
\hline 1986 & False killer whale & 1 & Mōkapu & O'ahu \\
\hline 1986 & Unidentified odontocete & 1 & Olowalu & Maui \\
\hline 1986 & Spotted dolphin & 1 & $\mathrm{Ka}^{6} \bar{o}^{6}$ io Point & O'ahu \\
\hline 1986 & Short-finned pilot whale & 1 & Kahului & Maui \\
\hline 1986 & Bottlenose dolphin & 1 & Bellows Beach & O'ahu \\
\hline 1986 & Melon-headed whale & 1 & Kū'au Bay & Maui \\
\hline 1986 & Striped dolphin & 1 & Kailua & O’ahu \\
\hline 1986 & Pygmy sperm whale & 1 & Kalaupapa & Moloka'i \\
\hline 1987 & Spinner dolphin & 1 & Hale iwa & O’ahu \\
\hline 1987 & Bottlenose dolphin & 1 & Wailua & Moloka'i \\
\hline 1987 & Dwarf sperm whale & 1 & Hauola Gulch & Lāna'i \\
\hline 1987 & Spotted dolphin & 1 & Mākaha & O’ahu \\
\hline 1987 & Rough-toothed dolphin & 1 & Waipi'o Bay & Hawai'i \\
\hline 1988 & Melon-headed whale & 1 & Mokulēia & O’ahu \\
\hline 1988 & Spinner dolphin & 1 & Kā‘anapali & Maui \\
\hline 1988 & Sperm whale & 1 & Ahukini & Kaua'i \\
\hline 1988 & Pygmy killer whale & 1 & Kīhei & Maui \\
\hline 1988 & Pygmy sperm whale & 1 & Punalu'u & O'ahu \\
\hline 1988 & Pygmy killer whale & 1 & Mā'alaea & Maui \\
\hline 1988 & Pygmy killer whale & 1 & Kìhei & Maui \\
\hline 1988 & Bottlenose dolphin & 1 & Pauwalu & Moloka ${ }^{\mathrm{i}}$ \\
\hline 1988 & Spinner dolphin & 1 & Nukumoi Point & Kaua'i \\
\hline 1988 & Risso’s dolphin & 1 & Pā'ia & Maui \\
\hline 1989 & Short-finned pilot whale & 1 & Wailau & Moloka ${ }^{6}$ \\
\hline 1990 & Stenella spp. & 1 & Honolulu & O’ahu \\
\hline 1990 & False killer whale & 1 & Hā'ena & Kaua'i \\
\hline 1990 & Bottlenose dolphin & 1 & Kualoa & O'ahu \\
\hline 1990 & Striped dolphin & 1 & Mākaha & O'ahu \\
\hline 1990 & Spinner dolphin & 1 & Mokule‘ia & O'ahu \\
\hline 1990 & Sperm whale & 1 & Po'ipū & Kaua'i \\
\hline 1991 & Bottlenose dolphin & 1 & Kīhei & Maui \\
\hline 1991 & Spinner dolphin & 1 & Open ocean & Hawai ${ }^{i} i$ \\
\hline 1992 & Sperm whale & 1 & Wailua Beach & Kaua'i \\
\hline 1992 & Sperm whale & 1 & Anahola Bay & Kaua'i \\
\hline 1992 & Kogia spp. & 1 & Makapu'u & $\mathrm{O}^{\prime} \mathrm{ahu}$ \\
\hline 1992 & Bottlenose dolphin & 1 & Pounders Beach & $\mathrm{O}^{\prime} \mathrm{ahu}$ \\
\hline
\end{tabular}


Appendix 1 (continued)

\begin{tabular}{|c|c|c|c|c|}
\hline Year & Species & $\begin{array}{c}\text { No. of } \\
\text { Individuals }\end{array}$ & Location & Island \\
\hline 1993 & Striped dolphin & 1 & Kāne'ohe & O'ahu \\
\hline 1993 & Spinner dolphin & 1 & Wai'anae & O'ahu \\
\hline 1993 & Pygmy sperm whale & 1 & Kekaha & Kaua'i \\
\hline 1993 & Striped dolphin & 1 & Kīhei & Maui \\
\hline 1993 & Sperm whale & 1 & Cape Kumukahi & Hawai'i \\
\hline 1993 & Spinner dolphin & 1 & Kōke‘e Beach & Kaua'i \\
\hline 1993 & Spinner dolphin & 1 & Anahola & Kaua'i \\
\hline 1993 & Pygmy sperm whale & 1 & Waiehu & Maui \\
\hline 1993 & Melon-headed whale & 1 & Ko Olina Resort & $\mathrm{O}^{\prime} \mathrm{ahu}$ \\
\hline 1994 & Spotted dolphin & 1 & KMCAS & O'ahu \\
\hline 1994 & Striped dolphin & 1 & Mā'alaea & Maui \\
\hline 1994 & Unidentified odontocete & 1 & Ka'ena Point & O'ahu \\
\hline 1994 & Spinner dolphin & 1 & Hanauma Bay & O'ahu \\
\hline 1994 & Spinner dolphin & 1 & Nānākuli Beach & O'ahu \\
\hline 1994 & Pygmy sperm whale & 1 & Kailua Beach & O'ahu \\
\hline 1994 & Spinner dolphin & 1 & Kāne'ohe & O'ahu \\
\hline 1994 & Spinner dolphin & 1 & Mokulēia & O'ahu \\
\hline 1994 & Spotted dolphin & 1 & Hau'ula & O'ahu \\
\hline 1994 & Sperm whale & 1 & Кара'а & Kaua'i \\
\hline 1995 & Kogia spp. & 1 & Waipi‘o Valley & Hawai'i \\
\hline 1995 & Melon-headed whale & 1 & Brennecke Beach & Kaua'i \\
\hline 1995 & Striped dolphin & 1 & Pāpōhaku Beach & Moloka'i \\
\hline 1995 & Short-finned pilot whale & 1 & Barking Sands & Kaua'i \\
\hline 1996 & Striped dolphin & 1 & Olowalu & Maui \\
\hline 1996 & Kogia spp. & 1 & Halepalaoa & Lāna'i \\
\hline 1996 & Pygmy sperm whale & 1 & Waikolo'a & Hawai'i \\
\hline 1996 & Short-finned pilot whale? & 1 & Hilo & Hawai'i \\
\hline 1996 & Sperm whale & 1 & Laupāhoehoe & Hawai'i \\
\hline 1996 & Melon-headed whale & 1 & Mākaha & O’ahu \\
\hline 1996 & Spotted dolphin & 1 & Kailua Beach & O'ahu \\
\hline 1996 & Kogia spp. & 1 & Waihe'e & Maui \\
\hline 1996 & Unidentified odontocete & 1 & Kailua-Kona & Hawai'i \\
\hline 1996 & Cuvier's beaked whale & 1 & Nānākuli & O'ahu \\
\hline 1997 & Unidentified odontocete & 1 & Nānākuli & $\mathrm{O}^{\prime} \mathrm{ahu}$ \\
\hline 1997 & Sperm whale & 1 & Kahuku & O'ahu \\
\hline 1997 & Spinner dolphin & 1 & Kailua & O'ahu \\
\hline 1997 & Striped dolphin & 1 & Waimānalo & $\mathrm{O}^{\prime} \mathrm{ahu}$ \\
\hline 1997 & Sperm whale & 1 & Waihe'e & Maui \\
\hline 1997 & False killer whale & 1 & Kailua-Kona & Hawai'i \\
\hline 1997 & Sperm whale & 1 & Kahuku & O’ahu \\
\hline 1997 & Spinner dolphin & 1 & Nānākuli & O'ahu \\
\hline 1997 & Striped dolphin & 1 & Hale'iwa & O'ahu \\
\hline 1998 & Bottlenose dolphin & 1 & Kama'ole Beach & Maui \\
\hline 1998 & Spinner dolphin & 1 & Spreckelsville & Maui \\
\hline 1998 & Bottlenose dolphin & 1 & Punalu'u Beach & $\mathrm{O}^{\prime} \mathrm{ahu}$ \\
\hline 1998 & Sperm whale & 1 & Anahola & Kaua'i \\
\hline 1998 & Cuvier's beaked whale & 1 & Wailua & Kaua' $\mathrm{i}$ \\
\hline 1998 & Bottlenose dolphin & 1 & Waialua & $\mathrm{O}^{\prime} \mathrm{ahu}$ \\
\hline 1998 & Pygmy sperm whale & 1 & Lahaina & Maui \\
\hline 1998 & Melon-headed whale & 1 & Keahou Bay & Hawai'i \\
\hline 1999 & Short-finned pilot whale & 1 & Kāne'ohe & O’ahu \\
\hline 1999 & Sperm whale & 1 & Kāne'ohe & O'ahu \\
\hline 1999 & Kogia spp.? & 1 & Ka'upa Bay & Maui \\
\hline 2000 & Unidentified odontocete & 1 & Po'ipū Harbor & Kaua'i \\
\hline 2000 & Dwarf sperm whale & 1 & Kailua Beach & O'ahu \\
\hline 2000 & Bottlenose dolphin & 1 & Lā'ie & O'ahu \\
\hline 2000 & Rough-toothed dolphin & 1 & Puakō & Hawai'i \\
\hline
\end{tabular}


Appendix 1 (continued)

\begin{tabular}{|c|c|c|c|c|}
\hline Year & Species & $\begin{array}{l}\text { No. of } \\
\text { Individuals }\end{array}$ & Location & Island \\
\hline 2000 & Spinner dolphin & 1 & Anahola & Kaua'i \\
\hline 2000 & Pygmy sperm whale & 1 & Hanalei Bay & Kaua'i \\
\hline 2000 & Spinner dolphin & 1 & Ka'ena Point & O'ahu \\
\hline 2000 & Dwarf sperm whale & 1 & Kailua & O'ahu \\
\hline 2001 & Pygmy sperm whale & 1 & Sugar Beach & Maui \\
\hline 2001 & Melon-headed whale & 1 & Mokulē'ia & O'ahu \\
\hline 2001 & Sperm whale & 1 & Kailua-Kona & Hawai'i \\
\hline 2001 & Spinner dolphin & 1 & Mokulē‘ia & O’ahu \\
\hline 2001 & Pygmy sperm whale & 1 & Kīhei & Maui \\
\hline 2001 & Rough-toothed dolphin & 1 & Kïhei & Maui \\
\hline 2001 & Unidentified odontocete & 1 & Alan Davis Beach & O'ahu \\
\hline 2001 & Dwarf sperm whale & 1 & Kīhei & Maui \\
\hline 2001 & Potted dolphin & 1 & Lācie & Hawai ${ }^{i} i$ \\
\hline 2001 & Striped dolphin & 1 & Kahuku & Hawai'i \\
\hline 2001 & Pygmy sperm whale & 1 & Sugar Beach & Maui \\
\hline 2001 & Melon-headed whale & 1 & Mokulēia & $\mathrm{O}^{\prime} \mathrm{ahu}$ \\
\hline 2001 & Sperm whale & 1 & Kailua-Kona & Hawai'i \\
\hline 2001 & Spinner dolphin & 1 & Mokulē'ia & O'ahu \\
\hline 2001 & Pygmy sperm whale & 1 & Kīhei & Maui \\
\hline 2001 & Rough-toothed dolphin & 1 & Kỉhei & Maui \\
\hline 2001 & Unidentified odontocete & 1 & Alan Davis Beach & O'ahu \\
\hline 2001 & Dwarf sperm whale & 1 & Kīhei & Maui \\
\hline 2001 & Spotted dolphin & 1 & Lā‘ie & Hawai'i \\
\hline 2001 & Striped dolphin & 1 & Kahuku & Hawai'i \\
\hline 2002 & Spotted dolphin & 1 & Pōka'ī Beach & O'ahu \\
\hline 2002 & Pygmy sperm whale & 1 & North Shore & Kaua'i \\
\hline 2002 & Pygmy sperm whale & 1 & Kinhei & Maui \\
\hline 2002 & Spinner dolphin & 1 & Magic Island & O’ahu \\
\hline 2002 & Dwarf sperm whale & 1 & Not reported & Moloka'i \\
\hline 2002 & Pygmy sperm whale & 1 & Mākena & Maui \\
\hline 2002 & Blainville's beaked whale & 1 & Kama'ole & Maui \\
\hline 2002 & Pygmy sperm whale & 1 & One'uli Beach & Maui \\
\hline 2002 & Unidentified odontocete & 1 & Keahau & Hawai ${ }^{i} i$ \\
\hline 2002 & Spotted dolphin & 1 & Pōka'ī Beach & O'ahu \\
\hline
\end{tabular}


